May 2012

\title{
Hidden voices of hermaphrodites
}

Zohra AsifJetha

Aga Khan University, zohra.jetha@aku.edu

Nasreen Sulaiman Lalani

Aga Khan University

Gulnar Akber Ali

Aga Khan University

Follow this and additional works at: https://ecommons.aku.edu/pakistan_fhs_son

Part of the Nursing Midwifery Commons

\section{Recommended Citation}

Jetha, Z. A., Lalani, N. S., Ali, G. A. (2012). Hidden voices of hermaphrodites. i-manager's Journal on Nursing, 2(2), 18-22.

Available at: https://ecommons.aku.edu/pakistan_fhs_son/147 


\title{
ARTICLES
}

\section{HIDDEN VOICES OF HERMAPHRODITES}

By

\author{
ZOHRA ASIF JETHA * \\ NASREEN SULAIMAN LALANI ** \\ GULNAR AKBER ALI *** \\ * Instructor, The Aga Khan University School of Nursing and Midwifery, Karachi, Pakistan. \\ **_*** Senior Instructor, The Aga Khan University School of Nursing and Midwifery, Karachi, Pakistan.
}

\begin{abstract}
Gender is a psychological component which is given by the society to a person, while sex is a biological component which is awarded by God. However, there are certain conditions in which the biological aspects are put to challenge with the social and psychological aspects of gender. Hermaphrodites are a third gender role, who is neither male or female, man nor woman but contains the element of both. One may question that if they are neither male nor female then who they are and whether they are equally treated in our society.

Looking at the challenges faced by hermaphrodites, one need to question what choices these hermaphrodites have in our society. We being a responsible citizen of the society, how can we make their lives less miserable and make them respectable or functional members of our society. This paper raises several questions to us: do these neglected and deprived community has means of education or employment; what possible choices can be offered to them other than begging, prostitution or dancing at weddings or baby showers. It is our responsibility as a society to treat them as humans and provide them social and legal rights so that they can also become an acceptable member of the society and can benefit the society with more sense of security and less burden.
\end{abstract}

Keyword: Gender, Hijras, Hermaphrodites, Psychological Aspects, Castration, Stigma, Burden, Rights.

\section{INTRODUCTION}

Rani, whom I met in a wedding ceremony is a girl hardly 20 years old, wearing a brightly colored dress with lots of makeup, specially dark lipstick on her lips. Probably through makeup, she was hiding some of the masculine features of herself. She was dancing on a loud music and collecting money from people. People were enjoying and making fun of her. One of the guests from the ceremony put money on his face and asked the girl to collect from his face. When she tried to pick that up, he held her hand and pinched her cheek. It was very embarrassing for me to look at this scene. After sometime, the dinner started and she stopped her dance. When everybody was busy in dinner, I saw her sitting in a corner having her dinner very quickly it was looking like she was very hungry. I went to her and greeted her; she looked at me and asked that why I am here? She inquired from me that, if I would like to invite her in any ceremony for performance otherwise I should leave this place because we are very bad people. I asked her that why she is doing this job, she gazed at me angrily and responded "will you give me any job at your home?" I am doing all this for my earnings, to feed and support my family. This selfish society is not for us." This simple question which she asked was not only for me but this question was for whole society. Who was he/she and why before giving her any answer one would think about it. This made me to think that is it a personal question or a general question for the entire society? Do we really feel that is it their choice to be born as a hermaphrodite and is it just to make fun on them? This paper will highlight some of the challenges faced by hermaphrodites in our part of the society and suggest certain ways to address these challenges.

Hermaphrodite or Hijras

Gender is a psychological component which is given by the society to a person, while sex is a biological component which is awarded by God. However, there are certain conditions in which the biological aspects are put to challenge with the social and psychological aspects of gender. Some conditions dominate the biology in shaping gender identity and influence on gender role. (Kessler \& McKenna as cited by Jami 2004). Hermaphrodites are a 


\section{ARTICLES}

third gender role, who is neither male nor female, but contains the element of both. One may question that if they are neither male nor female then who they are and whether they are equally treated in our society. Another definition "A hermaphrodite (or intersexes person) is someone who has some or all of the primary sex characteristics of both genders (for example, a penis and a vulva). There are three types of hermaphrodites: true, male pseudo and female pseudo" (Anonymous, 2011).

Hermaphrodite is a broader term used for those who are transgender, eunuch, transvestites, hijras, bisexuals or intersexes. In our part of the society, they are commonly called as hijras, khusra, chaka etc. Historically in Mughal era, the hermaphrodites were called Khowjasara. They were employed by Mughal rulers to take care of their harems. Khowajasara used to play potent roles in the court, held effective sway in the affairs of the state, and also acted as confidante of their master. However, with the fall of Mughal Empire, their status deteriorated and finally shackled to begging. By then, the hijras are considered as social outcasts, existing in a strange, no man's land (Jami, 2004).

\section{Types of Hermaphrodites}

Biologically, there are different categories of hermaphrodites. Commonly known are three conditions which cause them to be a hermaphrodite. First known as Klinefelter's syndrome a condition in which a genetic male actually has one or more extra $X$ chromosomes. The individual appears anatomically male but would not be male according to $\mathrm{XY}=$ boy formula. Second as Turner's syndrome, a condition in which an individual has one $X$ and no Y chromosome, thus they are neither an XY male nor a $X X$ female. Third, congenital adrenal hyperplasia or adrenogenital syndrome in which the adrenal glands produce an excess of androgens in utero (Wong, 1999).

The second category is Cross-dresser or transgender which also falls under the category of hijra. Cross-dressers are called Zananay and those are castrated. The operation referred to by hijras as a nirvan ("rebirth") and carried out by a Dai (traditional midwife) involves removing the penis and scrotum with a knife without anesthesia. This could be life threatening for them. Sahi Bukhari as cited by Jami (2004), in Islam, and Prophet Muhmmad has strongly prohibited the castration and forbade abstaining from marrying. Zananay claim that female soul is enclosed in their bodies since birth. The third category is of homosexuals and bisexual men who wear female clothes and are mostly observed to be involved in sex business.

While much is known and written about hermaphrodites in India; very little is documented about them in Pakistan. Coway (2002) tried to trace the prevalence of hijras in India and gave rough estimate of around 1,000,000 among over a billion people. There could be different reason for that because many people do not want to disclose their identity or they mention male gender on their identity card. According to Zehra (2010), it is estimated that there are up to 50,000 Hijras currently living in Pakistan. This estimate is hazy at best, due to the lack of a reliable consensus and, until recently, the lack of any institutional or public official acknowledgement that the Hijras of Pakistan exist at all.

\section{Challenges Faced by the Hermaphrodites}

There are multiple challenges the hermaphrodites and their families face in the society. These include; Stigma and discrimination from birth, Low Socio Economic Status due to Unemployment, Sexual Practices and Adverse Health Effects, Mental Health Issues among Hermaphrodite, Lack of Accessibility to Health and Education, Lack of Legal Rights, etc.

\section{Stigma and Discrimination from Birth}

It has been commonly observed that if the child is born with such biological defect, then the parents used to give up their child to this unisex community and thus the child is reared in their way (Jami (2004). Such parental actions are mostly taken under the influence of societal pressures or poverty. The parents feel this defect as a shame or a burden on them.

Hermaphrodites live in a close- knit community with defined family structures presided over by a leader (guru). Becoming a hijra is a process of socialization into a 'hijra family through relationship characterized as chela (student) to a guru (teacher)." (Jami 2004). They are living in the family and share earnings with guru. According to Tufail.S (2006) "in Sindh chellas have to turn over their full day's earnings to their guru who keeps 75 percent and 


\section{ARTICLES}

returns 25 percent to the chella. Household expenses are borne collectively. Non-resident chellas are supposed to come to their guru's home to pay a fixed amount and receive commodities on a monthly basis.

Hermaphrodites are considered physically and psychologically ambivalent and because of ambivalence people consider them freaks (hiding their sexual identity). Hermaphrodites are considered physically and psychologically undecided sex, and because of this they hide their personality (Coway,2002). Therefore, they are considered as a marginalized/stigmatized community. It has been commonly observed that these people are usually found on road side where they beg or dance or involved in some kind of sex business. Many of them are seen performing at various rituals/ceremonies such as marriage or child birth. Giving performance at a childs' birth is seen most common. According to Jami (2004), they go for asking Wadhai (alms) on child birth actually to confirm child's sexual identity. In case of sexual deformity, they claim the custody by declaring that the child belongs to them. However, the possibility of their taking away the child forcibly is remote. People see these hermaphrodites as a reason for fun and enjoyment to them. Hermaphrodites are unacceptable in society and not getting same value so they are doing these kind of acts to be noticed themselves, Jami (2004) "A person who is labeled as deviant starts finding outlets for expressing deviant behavior, desires or impulses as family, friends and society try to find the ways to forcibly culminate that".

\section{Low Socio Economic Status due to Unemployment}

Many a times because of the poverty or low socio economic status, some normal individuals do take up this way of living as hermaphrodites to earn money to feed their families. Poor and unemployed young male join this community as an easy access for money. Most of the people have been observed to give them money or extra favors due fear to avoiding their curse and get good wishes as part of their own belief systems. Moreover, most of the people are seen cracking vulgar jokes, using obscene language and throwing (making) vulgar gestures. Largely, people do not like to interact with hermaphrodites as they dislike them and hate the idea of having any hermaphrodite in the family

\section{Sexual Practices and Adverse Health Effects}

Involvement in various illegal sexual acts is another source of income for these hermaphrodites which make them vulnerable for the common Sexually Transmitted Infections (STIS). A STI survey found that 2 percent of Hijras were infected with HIV and 60 percent were infected with syphilis in Karachi, Pakistan (Hussain, 2006). Another study by United Nations Development Programme (UNDP), India (2010) in a Mumbai STI clinic reported very high HIV sero-prevalence of $68 \%$ and high syphilis prevalence of $57 \%$ among Hijras.

\section{Mental Health Issues among Hermaphrodite}

Hermophrodites go through several emotional problems due to fear, shame, lack of resource, lack of security, unawareness, poverty and non-acceptance in the society. All of these make them more vulnerable to get mental illness such as stress and depression and other mental disorders. The United Nations Development Programme (UNDP), India (2010) reports that depression and suicidal tendencies, possibly secondary to societal stigma, lack of social support, HIV status, and violence-related stress are commonly found among this community. Moreover, in order to combat these problems, these hermaphrodites indulge in various unhealthy practices such as smoking, drinking alcohol, and other substance abuse. Hijras provide several reasons justifying their alcohol consumption that range from the need to 'forget worries' (because there is no family support or no one cares about them) to managing rough clients in their sex work life (UNDP, 2010). In addition to the above, they also face all kinds of verbal and physical harassment and abuse commonly by the common people in the society. Qadri (2010) interviewed a hijra whose face was brutally disfigured by acid during a performance where he refused to accept any advance from a male admirer watching his performance.

\section{Lack of Accessibility to Health and Education}

With other several unmet needs, Hermaphrodites suffer lack of accessibility for health and education. If someone from this community tries to get education, the society attitude and behavior makes it difficult and meaningless for them. Not only education, they are also deprived of health and other psychological assistance. It is not uncommon 


\section{ARTICLES}

that the victims of gender identity go for castrations without any medical aid due to which sometimes death can occur. Often, they tend to use self-remedies which includes taking high doses of hormones over the counter which again endangers their lives. It is commonly observed in hospitals that they are not given proper treatment and attention if they visit for any medical aid or doctor, over the gender debate. One hijra reported waiting in the emergency room of a hospital for hours while medical staff debated whether to admit her to the men's or women's ward. (Anonymous, 2006). We don't see any hermophrodite in any respectable profession such as policeman, teacher or doctor and if they were, their identities are usually hidden or social or economic status may hide their weakness. According to Tufail (2006) "Educated English speaking class of eunuch is enlarging in Pakistan. They do not face this treatment because of their social and economic status in the society. They become fashion designers, interior decorators, hair stylists' etc."

\section{Lack of Legal Rights}

Hindrances such as cultural and social behavior of the society and stigmatization highly prevail towards this community. In Pakistan, there are no well-defined legal rights for this community and their status is undefined. Hermaphrodites should be treated equally and with justice and should be provided with legal rights in the society for better survival and societal growth and upliftment overall.

Looking at the above challenges, one need to question what choices these hermaphrodites have in our society. We being a responsible citizen of the society, how can we make their lives less miserable and make these hermaphrodites as respectable or functional members of our society. Usually, we sit in a close room in our own social gatherings to discuss about these people, but how many of us actually go to them and ask their needs and problems and have tried to assist them in changing the outlooks of their lives.

\section{Recommendations}

This paper would like to put forward certain recommendations individual, societal and at governmental level. We must realize that hermaphrodites are humans and therefore they should be treated like others. We are the ones who can speak for their rights. Zehra (2010) reported that two years ago, the Supreme Court of Pakistan under Justice Iftikhar Chaudry, implemented a series of legislations granting the Hijras in the country the right to a third gender category on their CNICs (Computerized National Identity Cards) instead of the usual "male" category they were made to register with earlier. With the current law in place, there is a hope that it may bring new change for this deprived community and provide them with a sense of identity. However, some of them may still choose to hide their identity.

Family awareness sessions should be arranged to impart proper knowledge and information regarding if the child is born with some sexual deformity. Moreover, to support them psychologically, counseling sessions for such families should be arranged and provided through media or other communication sources. Government/ local administration should arrange stipends and monetary assistance to the poor and provide employment to the affected sections of people. Moreover, government should arrange the medical assistance for affected individuals and enforce strict law to prohibit autocastration, and regular screening programme for them Those who are born with sexual deformity should be provided with financial psychological support help so that they could become acceptable in their own families and they should be given share in employment to lead normal life.

\section{Conclusion}

Hermaphrodites are part of our society who can't be ignored. What they are is because of the nature and not because of anybody's fault. We are no ones to stigmatize or blame them. They have equal rights to be treated fairly and without any injustice. We being the responsible citizens of the society must realize their challenges and therefore, must work towards facilitating and assisting this deprived and neglected community. We should provide them the means to good health and education and other facilities such as employment opportunities and legal rights so that they can live with respect and do not feel isolated. This would also prevent them to indulge in activities like begging, prostitution or dancing at weddings or baby 


\section{ARTICLES}

showers. Through our behavior and actions, we must try to treat them as humans and make them feel an acceptable member of the society. This would ultimately create a sense of security and safety among them and make them feel responsible and productive member rather than burden on the society.

\section{References}

[1]. Anonymous, (2006). Hijra (South Asia): from Wikipedia. Retrieved on December 11 th 2011, from http://en.wikipedia.org/wiki/Hijra_(South_Asia).

[2]. Coway, L. (2002). How Frequently Does Transsexualism Occur? Retrieved Oct 24, 2011 from http://ai.eecs.umich. edu/people/conway/TS/TSprevalence.html.

[3]. Hussian. S (2006). Poverty in Pakistan: Issues, causes and institutional responses. Retrieved on December 6th 2011 , fromhttp://www.adb.org/Documents/news/ PRM/2002.

[4]. Jami, H., (2004). Condition and status of hijras (transgender, transvestites etc.) in Pakistan. Retrieve on November 2nd 2011, fromhttp://web.com.hku/sjwinter/ transgender. htpp://web.hku.hk/sjwinter/TransgenderAsia/ index.htm.

[5]. Tufail. S (2006). Third Gender and Their Status in Pakistan Retrieved on January 11 th 2012 , from http://www.chowrangi.com/third-gender-and-their-status- in-pakistan.html

[6]. Wong, L.D. (1999). Whaley \& Wong's: Nursing care of infant and children. (5th ed). Mosby.

[7]. Zehra, A. (2010). PAKISTAN: Male to female identity in trans Hijra community brings flattery, hardship and discrimination Retrieved on January 11th 2012, from http://womennewsnetwork.net/category/wnn-breaking/ pakistan-wnn-breaking/.

[8]. United Nations Development Programme (UNDP) India (2010). Hijras/transgender women in india: hiv, human rights and social exclusion, Retrieved on March $26^{\text {th }} 2012$, from http://www.undp.org.in/sites/default/files/ reports_ publication/TG-issue-brief.pdf.

[9]. Qadri, M. (2010). Pakistan's hijras deserve acceptance Pakistanis must challenge the routine prejudice that condemns an ancient transgender community to violence and ridicule Retrieved on March $26^{\text {th }}$ 2012, from http://www.guardian.co.uk/commentisfree/2010/may/26/ pakistan-transgender-hijras-deserve-acceptance.

[10]. Anonymous. (2011). What is a hermaphrodite? Retrieved on March 25th 2012, from http://www.health24.com/sex/Sexual_diversity/1253-24442900,32501 .asp

\section{ABOUT THE AUTHORS}

Zohra Asif Jetha, BSCN, LHV currently working as an Instructor at the Aga Khan University School of Nursing and Midwifery, Karachi, Pakistan. I have 19yrs of experience in various areas of nursing practice and education. My major interests are medical surgical nursing, oncology nursing, and women and child nursing.

Nasreen Sulaiman Lalani, MScN, BSCN, RN currently working as a Sr. Instructor at the Aga Khan University School of Nursing and Midwifery, Karachi, Pakistan. I have 18yrs of experience in various areas of nursing practice and education. My major interests are medical surgical nursing, palliative nursing, women and nurse empowerment, and e-learning. I have done various national and international presentations and have got multiple publications in national and international journals both.

Gulnar Akber Ali, MSc, M.A, RN, Senior Instructor at Aga Khan University School of Nursing and midwifery, Karachi, Pakistan. My academic background ranges Medical Anthropology, Islamic Studies, Humanities and Mental Health Nursing. I am particularly interested in expanding exiting notion of nursing care on holistic grounds. My specialty lies in Forensic Mental health. Professional contribution includes several training programmes, publications and conference presentations at international level since 1998. 